\title{
A model for drug dispensing service based on the care process in the Brazilian health system
}

\author{
Luciano Soares ${ }^{1, *}$, Eliana Elisabeth Diehl², Silvana Nair Leite², Mareni Rocha Farias² \\ ${ }^{1}$ Departament of Pharmacy, University of the Region of Joinville, Joinvile, Santa Catarina, Brazil, ${ }^{2}$ Departament of \\ Pharmaceutical Sciences, Federal University of Santa Catarina, Florianópolis, Santa Catarina, Brazil
}

\begin{abstract}
Access to medication emphasizes the availability of the product at the expense of providing a service. The goal of this paper is to propose a theoretical model for a drug dispensing service, beginning with a reflection on the current realities of the Unified Health System and drug dispensation in Brazil. A conceptual analytical research made by a methodological course called disciplined imagination was mainly the approach applied to develop the model. The drug dispensing service is part of the care process, which considers access as an attribute; reception, connection and accountability, management, and clinical pharmaceutical aspects as components; and the rational use of drugs as the purpose. The proposed model addresses access to the dispensing service and demands a reorientation of routines, instruments, and practices.
\end{abstract}

Uniterms: Drugs/dispensing practice. Pharmaceutical service. Unified health system. Health services/ access.

O acesso a medicamentos enfatiza a disponibilidade do produto em detrimento da provisão de um serviço. O objetivo deste trabalho é propor um modelo teórico para um serviço de dispensação de medicamentos, iniciando com uma reflexão sobre a realidade atual do Sistema Único de Saúde e a dispensação de medicamentos no Brasil. Uma pesquisa analítica conceitual realizada por meio de um percurso metodológico chamado de imaginação disciplinada constituiu a estratégia principal para o desenvolvimento do modelo. O serviço de dispensação é parte do processo de cuidado, o qual considera o acesso como um atributo; os aspectos acolhimento, vínculo e responsabilização, gestão e clínica farmacêutica como componentes e o uso racional de medicamentos como o propósito. O modelo proposto direciona o acesso para o serviço de dispensação e demanda a reorientação de rotinas, instrumentos e práticas.

Unitermos: Medicamentos/prática de dispensação. Assistência farmacêutica. Sistema único de saúde. Serviços de saúde/acesso.

\section{INTRODUCTION}

The use of medications is steadily increasing (Lu et $a l ., 2011)$ and is a complex socioeconomic phenomenon with respect to ensuring drug accessibility, rational use, and the ability to solve health problems (Wiedenmayer $e t$ al., 2006). Worldwide, drug access systems are characterized by excessive and careless use, the deviation of drugs from their intended purpose, overestimated benefits, and a

\footnotetext{
*Correspondence: L. Soares. Universidade da Região de Joinville. Rua Paulo Malschitzki, 10, Campus Universitário - Zona Industrial - 89219-710 - Joinville - SC, Brasil. E-mail:soaresgnosia@gmail.com
}

high prevalence of drug-related problems (Wiedenmayer et al., 2006; Lu et al., 2011). The World Health Organization (WHO) has examined the role of pharmaceutical services and emphasized both their importance to health care and the difficulties involved in organizing such services in developing countries (World Health Organization, 1997; Wiedenmayer et al., 2006).

In terms of using the analytical categories of the health service utilization model developed by Andersen and Davidson (2007), the organization of drug dispensation can be viewed as a factor that enables the use of the service and influences access and health outcomes. In Brazil, medication costs may be covered by public health 
services, government-subsidized copayments, or private payments. Legally, pharmacies are considered to be either commercial enterprises operating under a health license or part of a health care unit (Brasil, 1973).

The Brazilian Constitution of 1988 guaranteed universal and equitable access to actions and services for the promotion, protection, and restoration of health (Brasil, 1988). These are the principles of the Unified Health System (Sistema Único de Saúde - SUS), the most significant social policy in Brazil, which provides pharmaceutical services, including drug dispensation (Brasil, 1990). However, during the establishment of the SUS, pharmacies remained isolated and disconnected from other health services and became anachronistic, continuing to comply with the regulatory framework of the 1970s, which characterized pharmacy as a medication trade (Brasil, 1973). Despite this situation, the direct purchase of drugs by the Brazilian government in 2008 exceeded 1 billion U.S. dollars according to the exchange rate on December 30, 2011 (Brasil, 2010). A contextual review of the Brazilian health system can be found in Paim et al. (2011).

Although the legal framework for drug dispensation has evolved, the product still affects the process, and the role of drugs as essential inputs for the care process has shifted to become the goal of the care itself. As a component of the health system, dispensation became a purely administrative activity, with an emphasis on issuing prescriptions and delivering drugs (Araújo, Freitas, 2006).

Brazilian studies have analyzed the inequities in the process of dispensation (Arrais, Barreto, Coelho, 2007; Angonesi, 2008). Although some studies have addressed relevant issues, researchers have rarely considered the fundamentals of the health system's construction, the health-care reform movement, and the effects of a market-driven economic system on dispensation (Gilbert, 1998; Riska, 2001; Bissell, Traulsen, 2005; Waterfield, 2010). Such studies reflect a dispensing practice that has developed without significant reflection on its theoretical framework, without evidence-based support and without considering the construction of pharmaceutical corporate knowledge. In this context, some questions remain: (1) Is drug dispensation designed to be a service in the health system? (2) How should dispensation be organized to incorporate the SUS principles of comprehensiveness, universality, and equity?

According to this context, there is a lack of theoretical framework throughout pharmaceutical service research. Therefore, there is a need to develop theoretical knowledge about drug dispensation to guide the development of the care process in the pharmacy and to allow reflection on the pharmacist's care practices within the context of public health services. The present article addresses this issue by proposing a theoretical model for a drug dispensing service, starting with a reflection on the realities of the SUS and dispensation in Brazil. The present work attempts to theoretically characterize drug dispensation as a service, setting out, for the first time, the access and the rational use of drugs connected to pharmaceutical service in the SUS context.

\section{METHODOLOGY}

The approach applied to develop this work was the conceptual analytical research as defined by Wacker (1998). In the theorizing and deducing process about the logical relations of objects, the methodological course called disciplined imagination comprises an evolutive process guided by the representation of reality. Theoretical variations of the conjectures replace the movements of the reality; the selection chooses theoretically the most adequate direction, which is selectively retained to avoid theoretical obstacles (Weick, 1989).

The development of the theory can be based on the synthesis of ideas obtained from the literature (Lee, Baskerville, 2003). The literature data to support the model-construction process was collected by searching Scientific Electronic Library Online (SciELO), PubMed, the Elsevier Science Publishing House, and Google Scholar.

It involved the construction and analysis of key components reflecting on drug dispensation in the SUS. The assumptions that guided the proposition of these components and their relations with their environment and context were explained, and the conceptual clarity and logical consistency in arguments were sought according to the criteria of Fawcett (1995).

\section{RESULTS AND DISCUSSIONS}

\section{The concept of drug dispensation in the literature}

Some authors (Arrais, Barreto, Coelho, 2007; Silva et al., 2008; James et al., 2009; Oishi, 2009) have proposed technical standards and procedures for the management or the policy related to the dispensation and technical management of drug treatments. These proposals can be summarized as follows: (1) legal standards intended to rationalize prescriptions and control psychoactive substance use and costs; (2) technical and administrative procedures related to the organization of the unit or the health system bureaucracy; and (3) procedures related to professional standards, technical and scientific knowledge, or professional culture. 
Angonesi (2008) reviewed the scientific literature and the laws of Brazil and several other countries and argued that there is little theoretical reflection on the subject and that discussions of regulatory aspects predominate. The commercial interface of dispensation has contributed to the field's fledgling scientific and technical-professional development.

Many studies do not explain their chosen concept or opt for a regulatory approach (Cheung, Bouvy, De Smet, 2009; Menolli, Ivama, Júnior, 2009; Panvelkar, Saini, Armour, 2009). The tacit assumptions that guide these studies seem to confine the dispensing activity to prescription checking; deliveries and instructions for the patient regarding drug conservation, administration, and precautions.

Classically, the pharmacy focuses on meeting the expectations of users and health professionals regarding drug availability and distribution. In the Brazilian public health services, pharmacies generally consist of small spaces for the storage and delivery of drugs, which occurs through a window and possibly bars. This environment reinforces the pharmacy's association with the regulatory model of access and a curative, physician-centered approach based on apparent patients' demands (Luiza, Castro, Nunes, 1999; Araújo, Ueta, Freitas, 2005; Araújo et al., 2008). The presence of a pharmacist is usually linked to the dispensation of psychoactive drugs (Silva, Vieira, 2004).

The drug dispensation in Brazil is regarded as a regulatory activity that consists of receiving the user, checking the prescription, separating and distributing the drugs, and advising the user (Moritz, 2010). The reality is characterized by a large number of patients served daily, although only a few patients have been treated by pharmacists. Its organization is centered on procedures prescribed in protocols and administrative resolutions, with legal aspects taking precedence over clinical aspects. The concern with access is focused on the availability of drugs, and clinical aspects are limited to the safety of medication management (Naves, Silver, 2005; Arrais, Barreto, Coelho, 2007; Menolli, Ivama, Júnior, 2009; Oishi, 2009).

Service is a process that applies resources and core professional competencies (knowledge and skills) for the benefit of another (Nelson, Sampat, 2001; Vargo, Lusch, 2004). Taking that into account and considering the situation previously described, we advocate that the current drug dispensation does not present such characteristics, which are essential to classify it on service domain. For this purpose, the social technology (as defined later) that concerns a dispensing service must be established, and specialized professional competencies must be systematized. These tasks should consider the knowledge and skills already embodied in pharmaceutical practice in the health system context.

\section{Proposed drug dispensing model for the Brazilian SUS}

The drug dispensing service should be integrated into the care process in the SUS, considering access as an attribute; the reception, connection, and accountability, management, and clinical pharmaceutical as the components; and the rational use of drugs as a purpose. Figure 1 summarizes the proposed model.

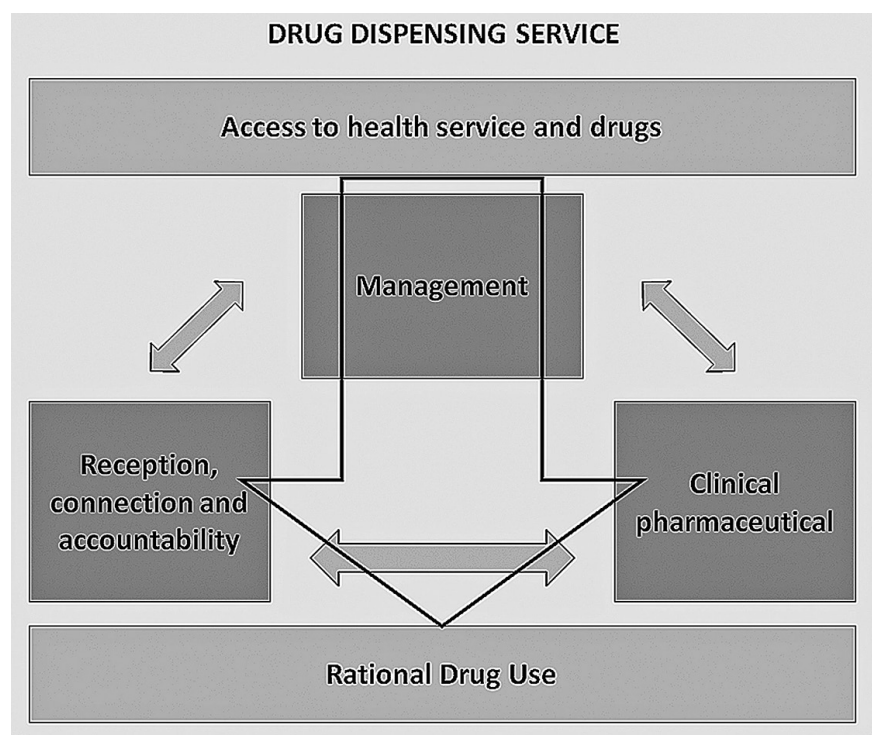

FIGURE 1 - Proposed model for drug dispensing service. Source: The authors

The proposed model has been grounded on service system framework to set both the role to be fulfilled by pharmacists and the drug dispensation's contribution in the health care system.

\section{Access to health services and drugs: An attribute of the dispensing service}

Drug dispensing services integrated into the SUS's care process should be responsible not only for drug dispensation but also for improving user access to services at all levels of care by identifying their needs and demands. The organization of public health services often determines the monthly dispensation of the prescription, whereas medical consultations occur at longer intervals (e.g., every three to six months).

Considering social technologies as the coordination of human actions that require interactions among different 
parts through the use of routines to achieve predictable and specifiable results as proposed by Nelson and Sampat (2001) and the characteristic autonomy of dispensary services, access to the dispensing service differs from access to drugs. Access to the dispensing service includes the ability to modify institutional relations (through new social technologies) within the service network. In this context, guaranteed access must consider accessibility, which includes such elements as the location of services, the conditions under which the patient may enter the system, and the roles of bureaucratic rules (Penchansky, Thomas, 1981). These aspects restrict opportunities, modulate individual and collective decisions about treatment, and stimulate user criticism (Trad et al., 2002; Ricketts, Goldsmith, 2005). Assuming that access to dispensation is affected by accessibility to health services, regardless of the legitimacy of the organizational form of these services, the pharmacy should help overcome prevailing inequities, even when this requires changing established technical routines and regulatory aspects.

The analysis of the relation between patients' perceived (what individual patients perceive as health needs) and assessed needs (professional judgments about each patient's state of health) and the health care process (the interactions among providers' and patients' behaviors in the production of care) (Andersen, Davidson, 2007) allows us to infer that the supply of drugs affects health behavior. Drug use tends to change according to the available modality, namely, either a drug (i.e., a physical technology disconnected from the process of care) or a dispensing service.

In the model proposed in the present work, the organization of the dispensing service supports and qualifies the access attribute. Respecting the principle of the user's centrality in the organization of the health system (Merhy, 2007) accepts the premise that guaranteed access should be the basis of the practice model and should represent the starting point for the care process. Access to dispensation as a service with relatively predictable specific routines from its own technical domain would be an essential technological component contributing to the effectiveness of the drugs by providing a new social technology and increased patient safety and reduced treatment costs.

\section{Reception, connection, and professional accountability: components of dispensation}

A change in dispensation involves the reorientation of the routines and social technologies. Adopting the premise that health care processes should be user centered, based on interactions among equals and relations that in- clude listening to and being accountable for the patient's needs, is to admit the need to follow the guidelines of reception, linking patients to their community and increasing the professional accountability for this care under a framework of comprehensiveness (Merhy, 2007).

Reception should guide the organization and intervention processes of the entire health service (Franco, Bueno, Merhy, 1999). Drug dispensation, in particular, should be integrated with the care process, helping to improve and consolidate previously developed practices. The pharmacist must "receive, listen and give a positive answer" (Franco, Bueno, Merhy, 1999), incorporating demands for drugs as part of patients' needs and helping to solve health problems. To ensure comprehensiveness, this reception cannot be a unilateral process and should incorporate the community's values to ease the tensions regarding the use of drugs and to define the pharmacistuser relationship, which should be founded on ethical principles and citizenship. This reorientation involves organizing the pharmacy to listen to users and encourage autonomy.

The characteristics and consequences of using drugs, either via self-medication or a prescription, modulate needs, the outcomes of which surpass institutional boundaries. To obtain consistent results, health systems must articulate the responses of various institutions providing various levels of health care. Primary health care (PHC) is considered to be an essential strategy in this articulation (World Health Organization, 1978), and many systems have adopted it when organizing care processes. It is relevant to the health service that drug dispensation in PHC accompanies and articulates a pharmacotherapeutic practice in which the patient participates, monitors emerging needs, and reorients relevant routines. This perspective assumes that the therapeutic itinerary can respond to changes that were not planned for in the protocols and requires professional and institutional collaboration and effective information management (Berg, 1997; Kleinman, Eisenberg, Good, 2006). Thus, dispensation is not limited to the physical space, and the focus of the service is the user's needs and the commitment to community health, reflecting the changes necessary to establish drug dispensation as a service within health systems. In this sense, incorporating reception as a technological component requires taking multidisciplinary and interdisciplinary action.

\section{The management component of the drug dispensing service}

Assuming that management capacity is "the capacity of an organization to decide with autonomy, flexibility 
and transparency, mobilizing resources and building the sustainability of management results" (Guimarães et al., 2004), three dimensions in the management process should be emphasized: organizational, operational, and sustainability. Barreto and Guimarães (2010) described characteristics, such as the understanding of the actors involved, decision-making autonomy, resource availability, participation, coordination, and partnership building as factors affecting the management of pharmaceutical services (Pan American Health Organization, 2011). These dimensions and constraints correspond with characteristics that limit the provision of a service (Meirelles, 2006; Maglio, Spohrer, 2008).

Management capacity, defined by the WHO as a key skill of the pharmacist in health care (World Health Organization, 1997), is a cardinal tool for planning and arranging the actions involved in organizing services and in the care process. The role of management must be recognized in performing the "work in act" (Merhy, 2002) of providing a drug dispensing service. The following management domains should be applied to the dispensing service: service organization and the mobilization of resources in the operational dimension; working conditions, personnel training, and coordination with the health team in the organizational dimension; and the workflow, the search for alliances, and the evaluation of results and satisfaction in the dimension of sustainability (Guimarães et al., 2004). The politicity and assessment-related aspects are linked to the sustainability dimension and are particularly relevant to the development of drug dispensation.

Regarding assessment, evidence-based management has gained importance in decisions about how to organize, structure, distribute, or finance health services (Walshe, Rundall, 2001). In Brazil, this practice takes shape through the evaluations of programs and services that seek to increase the coherence of public health system management (Novaes, 2000). In this sense, the evaluation of dispensation must converge on a service model in which management activities intersect with clinical activities.

Political skill is a fundamental part of building partnerships in the management of dispensation. Pharmacists should be aware of the political influence on the health care model, which stems from "political action of individuals and groups competing for the guidance of the health system" (Carvalho, Cunha, 2006). In this context, the goal is to establish a democratic health system in which the managements of policy and health work are a public issue (Merhy, 1997), and the political nature is a skill unveiled in the establishment of emancipatory care, which includes drug dispensation as a service. Management provides a structural axis of care in the dispensing service through the relations between the reception, connection and accountability, and the clinical pharmaceutical components.

\section{The clinical pharmaceutical component of the drug dispensing service}

Studies of drug-related morbidity and mortality reflect increasing problems with patient safety, reduced drug effectiveness, and high treatment costs (Ernst, Grizzle, 2001; Nishtala et al., 2011; Stark, John, Leidl, 2011). In Brazil, drugs are the leading registered cause of intoxication (Gandolfi, Andrade, 2006), and there is little consistent information about the effectiveness of pharmacotherapies, highlighting the urgent need for improvements in clinics' social technologies. We consider that clinical pharmaceutical service is an essential part of the professional pharmacist's work and should be developed in both theoretical dimension and pharmaceutical occupational culture.

The clinic can be understood as "a set of beliefs, positions, skills and attitudes aimed at reducing suffering, pain and disease and preventing death" (Favoreto, Camargo Jr, 2002). In a health system that has comprehensiveness as a principle, the "non-biomedical dimensions of diseases affect the plan of action for clinical practice" (Favoreto, Camargo Jr, 2002). As a component of dispensation, clinical pharmaceutical involves specific routines to optimize the use of drugs in therapeutic projects. For complex clinical situations, a pharmacotherapeutic followup based on a model adapted to the reality of the service is recommended.

Among the tools of clinical practice, protocols organize and standardize the therapeutic process (Ilott et al., 2006). However, it is necessary to reflect on the nature of these protocols because their rules sometimes ignore patient needs and can be reductionist in their dismissal of the complexity of health problems, limiting the availability of clinical options and critical professional performance (Berg, 1997).

The responsibility for proper outpatient care management is shared by the prescriber, the dispenser, and the user. The drug to be dispensed must possess all the characteristics that the prescription deems correct, with appropriate and effective use as the proposed outcome. The coresponsibility of the user deserves special attention in treatment management. The dispensation workflow must consider the subject's previous experiences, knowledge, beliefs, perceptions about his/her own health and his/her understanding of the problem; the complexity of the treatment; and the type of disease. These factors are associated with adherence and often modulate personal decisions 
about how to manage care (Leite, Vasconcellos, 2003; Gatti et al., 2009).

Supply information on the treatment and the inputs used to provide therapies and the corresponding attempt to get patient compliance are the most recognized activities of dispensation. However, the correlation between the provision of information and health outcomes is not clear (Loveman et al., 2003; Hayes et al., 2009; Brennan et al., 2012). An innovative clinic demands the careful selection of information based on the patient's cognitive abilities, his/her interests, needs and own sickness; promotes autonomy and education; and shares the power and responsibility for care. Shrank and Avorn (2007) analyzed the use of print media to convey information about pharmacotherapy and suggests a new readable and hierarchical approach to information presentation aimed at increasing the quality of communication.

A routine consisting of monitoring the patients' presenting signs and establishing their correlation with appropriate pharmacological treatments is strategic for dispensation. The clinical evaluation of pharmacotherapy should identify vulnerable groups of users. The health unit staff must share these responsibilities and agree on the systematic recording of data by multiple professionals to guide drug therapy management. In this sense, the relation with reception, connection, and accountability structures an interdisciplinary approach and may contribute to improved health outcomes.

\section{Rational drug use: The purpose of the drug dispensing service}

The promotion of rational drug use (RDU), a common pillar of drugs and pharmaceutical service policies in Brazil (Brasil, 1998, 2004) based on WHO guidelines, presents a growing challenge for equitable access. The WHO has defined that the rational use of drugs "demands that the appropriate drug be prescribed, that it be available at the right time at a price people can afford, that it be dispensed correctly, and that it be taken in the right dose at the right intervals and for the right length of time" (World Health Organization, 1987). This rationality articulates the role of clinical and epidemiological knowledge in the semiotic interpretation of disease (Souza, 1998), which, by compartmentalizing subjects, socially denies them and distances them from their suffering (Luz, 1988).

Although the term "use" may connote a user action, the RDU concept expresses many actions extrinsic to the subject such as prescribing appropriate medication. Furthermore, these actions comprise social technologies that are related to the outcomes, such as drug effective- ness and the curing of disease, which are multidetermined phenomena. These reflections reveal the epistemic gap at the root of the RDU concept and its implications for pharmaceutical practice.

The RDU concept can change according to the health system context in which it is applied (Almarsdóttir, Traulsen, 2005). To assess the rationality of use, the pharmacotherapeutic regimen should be considered within the context of the individual treatment plan, with proper interactions among health care levels. These observations indicate that rational use is a behavior of the service providers, expressed in the care process as a social phenomenon within the health system.

Improved drug dispensation can help establish a framework for rationality that is more consistent with the reality of health systems that follow the principles of equity and comprehensiveness, as Brazil's health care system does. The RDU recommends reducing the indiscriminate use of drugs by patients and providers to alleviate the consequences of the high prevalence of iatrogenic artifacts, increasing complex drug interactions, and increasing severe adverse effects (Stark, John, Leidl, 2011). In this context, the dispensing service must promote RDU while maintaining the patient's autonomy as its central guideline and legitimizing, along with the team, the recognition that the patient is an active participant in the therapeutic project.

Rational use resulting from the proposed dispensing service does not indicate that one should be determined by the other. Drug treatment is recognized as a complex phenomenon, and its appropriateness is a challenge to the dispensing service. RDU is an important condition for achieving the desired treatment results but should not be regarded as the sole purpose of the care itself. Rationalizing the use of drugs arises from organizing access to the dispensing service and is not solely the result of ensuring access to drugs.

\section{CONCLUSION}

The role of the pharmaceutical service is linked to pharmacists' abilities to reflect on their professional practice and discover the health system's contributions. The use of drugs as a health care technology should be studied and improved to increase the benefits to users and ensure their access to appropriate services. The current dispensing service, which includes professional efforts and is manifested by live labor, lacks the organization and theoretical support needed to contribute to the health system's purpose.

The proposed theoretical model of the drug dispensing service began with the assumption that, at least in part, 
drugs are responsible for the observed treatment results and that their availability and distribution alone are insufficient to meet patients' needs. The model includes access as an attribute and rational drug use as its purpose. In the model, the dispensing service is envisioned as integrating management, reception, connection, and accountability, and clinical pharmaceutical as a means of providing qualified drug treatment. Proposed clinical pharmaceutical is a novelty because we design it as part of drug dispensation, and it should be provided to all patients.

As with most models, the proposed model is intentionally simplistic to promote understanding. We recognize the importance of work process discussions in guiding the drug dispensing service model. However, because of the complexity of the subject, such discussions were not used in constructing the model and are therefore not addressed in this work. Empirical studies applying the model could broaden its theoretical support.

The proposal of a service model for drug dispensation in the SUS opens the discussion on access to this service, its theoretical foundation, and the occupational culture. The complexity of the issue requires a broad debate in the pharmaceutical sciences, with the aim of improving the model and amplifying its perspective. Although the proposed model is rooted in a Brazilian context, it can potentially be adapted to other countries. The context of the health system determines the organization of the services; however, some principles postulated here may be useful and valid in other contexts.

\section{ACKNOWLEDGMENTS}

The authors are grateful to the Programa de PósGraduação em Farmácia, PGFAR, Universidade Federal de Santa Catarina, Florianópolis, SC, Brazil, and to the Fundo de Apoio à Pesquisa, Universidade da Região de Joinville, Joinville, SC, Brazil.

\section{REFERENCES}

ALMARSDÓTTIR, A.B.; TRAULSEN, J.M. Rational use of medicines - an important issue in pharmaceutical policy. Pharm. World Sci., v.27, n.2, p.76-80, 2005.

ANDERSEN, R.M.; DAVIDSON, P.L. Improving access to care in America: Individual and Contextual Indicators. In: ANDERSEN, R.R.T.H.; KOMINSKI, G.F. (Eds.). Changing the U.S. health care system. 3ed. San Francisco: John Wiley \& Sons, Inc., 2007. p.3-30.
ANGONESI, D. Dispensação farmacêutica: uma análise de diferentes conceitos e modelos. Ciên. Saúde Colet., v.13, supp.1, p.629-640, 2008.

ARAÚJO, A.; UETA, J.; FREITAS, O. Pharmaceutical service as a technological model in primary health care. Braz. J. Pharm. Sci., v.26, n.2, p.87-92, 2005.

ARAÚJO, A.L.A.; FREITAS, O. Concepções do profissional farmacêutico sobre a assistência farmacêutica na unidade básica de saúde: Dificuldades e elementos para a mudança. Braz. J. Pharm. Sci., v.42, n.1, p.137-146, 2006.

ARAÚJO, A.L.A.; PEREIRA, L.R.L.; UETA, J.M.; FREITAS, O. Perfil da assistência farmacêutica na atenção primária do Sistema Único de Saúde. Ciên. Saúde Colet., v.13, supp.1, p.611-617, 2008.

ARRAIS, P.S.D.; BARRETO, M.L.; COELHO, H.L.L. Aspectos dos processos de prescrição e dispensação de medicamentos na percepção do paciente: estudo de base populacional em Fortaleza, Ceará, Brasil. Cad. Saúde Pública, v.23, n.4, p.927-937, 2007.

BARRETO, J.L.; GUIMARÃES, M.C.L. Avaliação da gestão descentralizada da assistência farmacêutica básica em municípios baianos, Brasil. Cad. Saúde Pública, v.26, n.6, p.1207-1220, 2010.

BERG, M. Problems and promises of the protocol. Soc. Sci. Med., v.44, n.8, p.1081-1088, 1997.

BISSELL, P.; TRAULSEN, J.M. Sociology and pharmacy practice. London: Pharmaceutical Press, 2005. 226 p.

BRASIL. Lei n. 5.991, de 17 de dezembro de 1973. Dispõe sobre o controle sanitário do comércio de drogas, medicamentos, insumos farmacêuticos e correlatos, e dá outras providências. Diário Oficial, 19 dez. 1973. Brasília - DF: Imprensa Nacional, 1973. Seção 1, p.13049.

BRASIL. Constituição da República Federativa do Brasil de 1988. Diário Oficial, 05 out. 1988. Brasília - DF: Imprensa Nacional, 1988. Seção 1, p.1.

BRASIL. Lei n. 8.080, de 20 de setembro de 1990. Dispõe sobre as condições para a promoção, proteção e recuperação da saúde, a organização e o funcionamento dos serviços correspondentes e dá outras previdências. Diário Oficial, 20 set. 1990. Brasília - DF: Imprensa Nacional, 1990. Seção 1, p. 18055 . 
BRASIL. Portaria MS n. 3.916, de 30 de outubro de 1998. Política Nacional de Medicamentos. Diário Oficial, 10 nov. 1998. Brasília - DF: Imprensa Nacional, 1998. Seção 1, p.18.

BRASIL. Resolução CNS n. 338, de 6 de maio de 2004. Política Nacional de Assistência Farmacêutica. Diário Oficial da União, 20 maio 2004. Brasília - DF: Imprensa Nacional, 2004. Seção 1, p.52.

BRASIL. Secretaria de Assuntos Estratégicos da Presidência da República. Instituto de Pesquisa Econômica Aplicada. Programas de Assistência Farmacêutica do Governo Federal: evolução recente das compras diretas de medicamentos e primeiras evidências de sua eficiência, 2005 a 2008. Comunicados do IPEA. Brasília: IPEA, 2010. 1-25 Available at: <http://www.ipea.gov.br/portal/images/ stories/PDFs/comunicado/101216_comunicadoipea74. pdf $>$. Accessed on: 23 feb 2012.

BRENNAN, T.A.; DOLLEAR, T.J.; HU, M.; MATLIN, O.S.; SHRANK, W.H.; CHOUDHRY, N.K.; GRAMBLEY, W. An Integrated Pharmacy-Based Program Improved Medication Prescription And Adherence Rates In Diabetes Patients. Health Aff., v.31, n.1, p.120-129, 2012.

CARVALHO, S.R.; CUNHA, G.T. A gestão da atenção na saúde: elementos para se pensar a mudança da organização na saúde. In: CAMPOS, G.; MINAYO, M.; AKERMAN, M.; DRUMOND Jr., M.; CARVALHO, Y.M. (Eds.). Tratado de saúde coletiva. São Paulo: Hucitec; Rio de Janeiro: Fiocruz, 2006. p. $837-868$.

CHEUNG, K.C.; BOUVY, M.L.; DE SMET, P.A.G.M. Medication errors: the importance of safe dispensing. Br. J. Clin. Pharmacol, v.67, n.6, p.676-680, 2009.

ERNST, F.R.; GRIZZLE, A.J. Drug-related morbidity and mortality: updating the cost-of-illness model. J. Am. Pharm. Assoc., v.41, n.2, p.192-199, 2001.

FAVORETO, C.A.O.; CAMARGO Jr., K. Alguns desafios conceituais e técnico-operacionais para o desenvolvimento do Programa de Saúde da Família como uma proposta transformadora do modelo assistencial. Physis, v.12, n.1, p.59-76, 2002.

FAWCETT, J. Analysis and evaluation of conceptual models of nursing. Philadelphia: F. A. Davis, 1995. 576 p.
FRANCO, T.B.; BUENO, W.S.; MERHY, E.E. O acolhimento e os processos de trabalho em saúde: o caso de Betim, Minas Gerais, Brasil. Cad. Saúde Pública, v.15, n.2, p.345-353, 1999.

GANDOLFI, E.; ANDRADE, M.G.G. Eventos toxicológicos relacionados a medicamentos no Estado de São Paulo. Rev. Saúde Pública, v.40, n.6, p.1056-1064, 2006.

GATTI, M.E.; JACOBSON, K.L.; GAZMARARIAN, J.A.; SCHMOTZER, B.; KRIPALANI, S. Relationships between beliefs about medications and adherence. Am. J. HealthSyst. Pharm., v.66, n.7, p.657-664, 2009.

GILBERT, L. Dispensing doctors and prescribing pharmacists: a south african perspective. Soc. Sci. Med., v.46, n.1, p.8395, 1998.

GUIMARÃES, M.C.L.; SANTOS, S.M.C.; MELO, C.; SANCHES FILHO, A. Avaliação da capacidade de gestão de organizações sociais: uma proposta metodológica em desenvolvimento. Cad. Saúde Pública, v.20, n.6, p.16421650, 2004.

HAYES, T.L.; LARIMER, N.; ADAMI, A.; KAYE, J.A. Medication adherence in healthy elders. J. Aging Health, v.21, n.4, p.567-580, 2009.

ILOTT, I.; RICK, J.; PATTERSON, M.; TURGOOSE, C.; LACEY, A. What is protocol-based care? A concept analysis. J. Nurse. Manag., v.14, n.7, p.544-552, 2006.

JAMES, K.L.; BARLOW, D.; MCARTNEY, R.; HIOM, S.; ROBERTS, D.; WHITTLESEA, C. Incidence, type and causes of dispensing errors: a review of the literature. Int. J. Pharm. Pract., v.17, p.9-30, 2009.

KLEINMAN, A.; EISENBERG, L.; GOOD, B. Culture, illness, and care: clinical lessons from anthropologic and crosscultural research. Reprinted Annals of Internal Medicine 1978. Focus, v.4, n.1, p.140-149, 2006.

LEE, A.S.; BASKERVILLE, R.L. Generalizing generalizability in information systems research. Inf. Sys. Res., v.14, n.3, p.221-243, 2003.

LEITE, S.N.; VASCONCELLOS, M.P.C. Adesão à terapêutica medicamentosa: elementos para a discussão de conceitos e pressupostos adotados na literatura. Ciên. Saúde Colet., v.8, n.3, p.775-782, 2003. 
LOVEMAN, E.; CAVE, C.; GREEN, C.; ROYLE, P.; DUNN, N.; WAUGH, N. The clinical and cost-effectiveness of patient education models for diabetes: a systematic review and economic evaluation. Health Technol. Assess., v.7, n.22, p.1-6, 2003. Available at: <http://eprints.soton. ac.uk/72883/1/mon1209.pdf>. Accessed on: 23 fev 2012.

LU, Y.; HERNANDEZ, P.; ABEGUNDE, D.; EDEJER, T. Medicine Expenditures. In: WORLD HEALTH ORGANIZATION (Ed.). The world medicines situation 2011. 3ed. Geneva: WHO Press, 2011. p.1-32.

LUIZA, V.L.; CASTRO, C.G.S.O.; NUNES, J.M. Aquisição de medicamentos no setor público: o binômio qualidade-custo. Rev. Saúde Publ., v.15, n.4, p.769-776, 1999.

LUZ, M.T. Natural, racional, social: discussão de uma sociabilidade. Rio de Janeiro: Campus, 1988. 152 p.

MAGLIO, P.P.; SPOHRER, J. Fundamentals of service science. J. Acad. Mark. Sci., v.36, n.1, p.18-20, 2008.

MEIRELLES, D.S. O conceito de serviço. Braz. J. Polit. Econ., v.26, n.1, p.119-136, 2006.

MENOLLI, P.V.S.; IVAMA, A.M.; JÚNIOR, L.C. Caracterización de los servicios farmacéuticos de atención primaria del Sistema Único de Salud en Londrina, Paraná, Brasil. Pan Am. J. Public Health, v.25, n.3, p.254-259, 2009.

MERHY, E.E. Em busca do tempo perdido: a micropolítica do trabalho vivo em ato, em saúde. In: MERHY, E.E.; ONOCKO, R. (Ed.). Agir em saúde: um desafio para o público. São Paulo: Hucitec, 1997. cap.2, p.71-112.

MERHY, E.E. Saúde: a cartografia do trabalho vivo. São Paulo: Hucitec, 2002. 189 p.

MERHY, E.E. O trabalho em saúde: olhando e experienciando o SUS no cotidiano. 4ed. São Paulo: Editora Hucitec, 2007. $296 \mathrm{p}$.

MORITZ, Â.F.E. Satisfação do usuário com a dispensação de medicamentos para o tratamento da Aids no Brasil: contribuições para o desenvolvimento de um modelo de avaliação. Rio de Janeiro, 2010. 113 p. [Thesis of PhD degree.Faculty of Public Health, Nacional School of Health Public Sérgio Arouca].
NAVES, J.O.S.; SILVER, L.D. Avaliação da assistência farmacêutica na atenção primária no Distrito Federal. Rev. Saúde Pública, v.39, n.2, p.223-230, 2005.

NELSON, R.R.; SAMPAT, B.N. Making sense of institutions as a factor shaping economic performance. J. Econ. Behav. Organ., v.44, n.1, p.31-54, 2001.

NISHTALA, P.S.; MCLACHLAN, A.J.; BELL, J.S.; CHEN, T.F. A retrospective study of drug related problems in Australian aged care homes: medication reviews involving pharmacists and general practitioners. J. Eval. Clin. Pract., v.17, n.1, p.97-103, 2011.

NOVAES, H.M.D. Avaliação de programas, serviços e tecnologias em saúde. Rev. Saúde Pública, v.34, n.5, p.547549, 2000.

OISHI, R. Current status of preparation and distribution of medicines. Am. J. Health-Syst. Pharm., v.66, n.5, suppl.3, p.S35-S42, 2009.

PAIM, J.; TRAVASSOS, C.; ALMEIDA, C.; BAHIA, L.; MACINKO, J. The Brazilian health system: history, advances, and challenges. Lancet, v.377, p.1778-1797, 2011.

PAN AMERICAN HEALTH ORGANIZATION. Guidelines for the development of pharmaceutical services in primary health care. Draft. Washington: PAHO, 2011. 81 p. Available at: $<$ http://new.paho.org/hq/index.php $>$. Accessed on: may 2012.

PANVELKAR, P.N.; SAINI, B.; ARMOUR, C. Measurement of patient satisfaction with community pharmacy services: a review. Pharm. World Sci., v.31, n.5, p.525-537, 2009.

PENCHANSKY, R.; THOMAS, J.W. The concept of access: definition and relationship to consumer satisfaction. Med. Care, v.19, n.2, p.127-140, 1981.

RICKETTS, T.C.; GOLDSMITH, L.J. Access in health services research: the battle of the frameworks. Nurs. Outlook, v.53, n.6, p.274-280, 2005.

RISKA, E. Towards gender balance: but will women physicians have an impact on medicine? Soc. Sci. Med., v.52, p.179$187,2001$. 
SHRANK, W.H.; AVORN, J. Educating patients about their medications: the potential and limitations of written drug information. Health Aff., v.26, n.3, p.731-740, 2007.

SILVA, A.E.B.C.; ADRIANA, I.M.; OLIVEIRA, R.C.; FAKIH, F.T.; GIMENES, F.R.E.; DIVALDO, P.; CASSIANI, S.H.B. The Process of Drug Dispensing and Distribution at Four Brazilian Hospitals: a Multicenter Descriptive Study. Lat. Am. J. Pharm., v.27, n.3, p.446-453, 2008.

SILVA, L.R.; VIEIRA, E.M. Conhecimento dos farmacêuticos sobre legislação sanitária e regulamentação da profissão. Rev. Saúde Pública, v.38, n.3, p.429-437, 2004.

SOUZA, A.R.N.D. Formação médica, racionalidade e experiência: o discurso médico eo ensino da clínica. Rio de Janeiro, 1998. 290 p. [Thesis of PhD degree. Institute of Psyquiatry, Federal University of Rio de Janeiro].

STARK, R.G.; JOHN, J.; LEIDL, R. Health care use and costs of adverse drug events emerging from outpatient treatment in Germany: a modelling approach. BMC Health Serv. Res., v.11, n.9, p.1-9, 2011.

TRAD, L.A.B.; BASTOS, A.C.S.; SANTANA, E.M.; NUNES, M.O. Estudo etnográfico da satisfação do usuário do programa de saúde da família (PSF) na Bahia. Ciênc. Saúde Coletiva, v.7, n.3, p.581-589, 2002.

VARGO, S.L.; LUSCH, R.F. Evolving to a new dominant logic for marketing. J. Marketing, v.68, n.1, p.1-17, 2004.

WACKER, J.G. A definition of theory: research guidelines for different theory-building research methods in operations management. J. Oper. Manag., v.16, n.4, p.361-385, 1998.

WALSHE, K.; RUNDALL, T.G. Evidence based management: from theory to practice in health care. Milbank $Q$., v.79, n.3, p.429-457, 2001.
WATERFIELD, J. Is pharmacy a knowledge-based profession? Am. J. Pharm. Educ., v.74, n.3, p.1-6, 2010.

WEICK, K.E. Theory construction as disciplined imagination. Acad. Manage. Rev., v.14, n.4, p.516-531, 1989.

WIEDENMAYER, K.; SUMMERS, R.S.; MACKIE, C.A.; GOUS, A.G.S.; EVERARD, M.; TROMP, D. Pharmacists in the health care team: a policy perspective. Developing pharmacy practice: a focus on patient care. Handbook 2006 edition. The Hague: World Health Organization and International Pharmaceutical Federation, 2006. v.2, 22 p.

WORLD HEALTH ORGANIZATION. Declaration of AlmaAta: International Conference on Primary Health Care, Alma-Ata, USSR, 6-12 September 1978. Alma-Ata: WHO, 1978. Available at: <http://www.who.int/publications/ almaata_declaration_en.pdf $>$. Accessed on: 23 feb 2012.

WORLD HEALTH ORGANIZATION. The rational use of drugs. Report of the conference of experts nairobi, 29 November 1985. Geneva: World Health Organization, $1987.338 \mathrm{p}$.

WORLD HEALTH ORGANIZATION. The role of the pharmacist in the health care system - preparing the future pharmacist: curricular development, report of a third WHO consultative group on the role of the pharmacist Vancouver, Canada, 27-29 August 1997. Vancouver: World Health Organization, 1997.

Received for publication on $28^{\text {th }}$ May 2012 Accepted for publication on $21^{\text {st }}$ November 2012 